\title{
Membrane staining for hepatitis B surface antigen on hepatocytes: a sensitive and specific marker of active viral replication in hepatitis $B$
}

\author{
C-M Chu, Y-F Liaw
}

\begin{abstract}
Aims-To test the hypothesis that membranous staining of hepatitis $B$ surface antigen (HBsAg) on the hepatocyte is a marker of active viral replication in chronic hepatitis B virus (HBV) infection. Methods-Intrahepatic expression of HBsAg and hepatitis $B$ core antigen (HBcAg) was studied by indirect immunofluorescence on frozen sections of liver specimens from 75 patients with chronic hepatitis $B$, and the results were correlated with serum levels of HBV-DNA assayed by spot hybridisation.

Results-Hepatocyte HBcAg was detected in all of 20 patients with serum levels of HBV-DNA $>1000 \mathrm{pg} / \mathrm{ml}, 18(75 \%)$ of 24 patients with levels of HBV-DNA $\leq 1000 \mathrm{pg} / \mathrm{ml}$, and two $(6 \cdot 5 \%)$ of 31 patients without detectable serum HBV-DNA. The concordance between hepatocyte HBcAg and serum HBV-DNA was $89 \cdot 3 \%$ (67/75). There were six patients $(8 \%)$ who had detectable serum HBV-DNA but without hepatocyte HBcAg, and two patients (2.7\%) who had detectable hepatocyte HBcAg but without serum HBV-DNA. Membranous staining of HBsAg associated with variable degrees of cytoplasmic HBsAg was found in all but one of 44 patients with serum HBV-DNA, irrespective of the levels, but in none of the 31 patients without serum HBV-DNA. Of the latter, HBsAg was distributed solely in the cytoplasm. In addition, there is an inverse correlation between serum levels of HBV-DNA and the degrees of cytoplasmic staining of HBsAg. The concordance between membranous staining of HBsAg and serum HBV-DNA was $\mathbf{9 8 \cdot 7 \%}$ (74/75), significantly higher than that between hepatocyte HBcAg and serum HBVDNA.

Conclusions-Membranous staining of
\end{abstract} HBsAg on the hepatocyte correlated excellently with serum HBV-DNA and thus can be recognised as a sensitive and specific marker of active hepatitis $B$ virus replication.

(f Clin Pathol 1995;48:470-473)

Keywords: Hepatitis B, HBV-DNA, HBsAg, HBcAg, immunostaining.

Previous immunohistochemical studies have suggested that hepatocyte expression of hepatitis $\mathrm{B}$ core antigen $(\mathrm{HBcAg})$ had a significant diagnostic and prognostic implication in patients with chronic hepatitis B virus (HBV) infection. ${ }^{1-8}$ The demonstration of $\mathrm{HBcAg}$ in liver usually correlated with active viral replication and was associated with variable degrees of inflammatory activity in the liver, while failure to detect $\mathrm{HBcAg}$ in liver usually indicated low levels of viral replication and was associated with little or no inflammatory activity. ${ }^{1-8}$ Assays of HBV-DNA in serum by molecular hybridisation techniques have long been recognised as a sensitive and specific method of evaluating viral replication in chronic hepatitis $B$ virus infection. ${ }^{9-11}$ However, these earlier data have shown that the discordance between serum HBV-DNA and hepatocyte expression of $\mathrm{HBcAg}$ ranged from $12 \%$ to $23 \%$, including (1) 9-23\% of patients who were positive for serum HBV-DNA without hepatocyte $\mathrm{HBcAg}$ and (2) $0-3 \%$ of patients who had hepatocyte expression of $\mathrm{HBcAg}$ without serum HBV-DNA..$^{12-15}$ One possible reason for the former might be sampling error in the biopsy specimens because hepatocyte expression of $\mathrm{HBcAg}$ could be only focal in certain patients with chronic hepatitis $B^{1617}$; in the case of the latter, false positive immunostaining of $\mathrm{HBcAg}$ cannot be excluded. ${ }^{18}$

It has been shown that there is membranous staining of HBsAg associated with variable degrees of cytoplasmic staining of HBsAg during the phase of active hepatitis $B$ virus replication and, by the contrast, solely cytoplasmic staining of HBsAg during the non-replicative phase. ${ }^{12519}$ Of note is that the distribution of membranous staining of $\mathrm{HBsAg}$ is usually diffuse and the staining intensity is rather strong during active viral replication. ${ }^{12519}$ It is therefore postulated that immunostaining of $\mathrm{HBsAg}$ on the hepatocyte membrane might be more sensitive and specific than immunostaining of $\mathrm{HBcAg}$ as a marker of active hepatitis B virus replication. To test this hypothesis, serum levels of HBV-DNA were correlated with membranous staining of HBsAg on the hepatocyte versus hepatocyte staining of $\mathrm{HBcAg}$ in 75 patients with chronic hepatitis $B$.

\section{Methods}

Seventy five patients with chronic HBV infection were studied. All had been HBsAg positive for more than six months before a histological diagnosis of chronic hepatitis was made. Forty four patients were seropositive for $\mathrm{HBeAg}$ and the other 31 were seropositive for antibody against $\mathrm{HBeAg}$ (anti-HBe). All were
Correspondence to: Dr Chia-Ming Chu Accepted for publication 26 September 1994 
Table 1 Mean (SEM) clinical and laboratory data of patients studied

\begin{tabular}{lllllc}
\hline Category & No of cases & $\begin{array}{l}\text { Age } \\
\text { (years) }\end{array}$ & $\begin{array}{l}\text { Sex } \\
\text { (M:F) }\end{array}$ & $\begin{array}{l}\text { AST (IUIl) } \\
(n<40)\end{array}$ & $\begin{array}{l}\text { ALT (IU/l) } \\
(N<40)\end{array}$ \\
\hline HBeAg positive CPH & 22 & $24(3)$ & $18: 4$ & $48(2)$ & $60(3)$ \\
HBeAg positive CAH & 22 & $29(2)$ & $20: 2$ & $84(8)$ & $202(18)$ \\
Anti-HBe positive CAH & 5 & $33(2)$ & $5: 0$ & $80(30)$ & $180(40)$ \\
Anti-HBe positive MHC & 26 & $35(1)$ & $24: 2$ & $29(3)$ & $34(3)$ \\
\hline
\end{tabular}

$\mathrm{HBeAg}=$ hepatitis $\mathrm{B}$ e antigen; anti-HBe $=$ antibody against $\mathrm{HBeAg} ; \mathrm{CPH}=$ chronic persisten hepatitis; $\mathrm{CAH}=$ chronic active hepatitis; $M H C=$ minimal histological changes.

negative for antibody against hepatitis $\delta$ virus (anti-HDV). None admitted intravenous drug abuse, nor had they ever received antiviral or immunosuppressive treatment. The histological diagnosis of chronic hepatitis was made according to standard criteria. ${ }^{20}$ The clinical and laboratory data of the patients studied are listed in table 1.

Serum aspartate transferase (AST) and alanine transaminase (ALT) were measured by sequential multiple autoanalysers. Serum HBsAg, HBeAg, anti-HBe, and anti-HDV were assayed using commercially available radioimmunoassay kits (Ausria-II, $\mathrm{HBeAg}$ RIA, and anti-delta, Abbot Laboratories).

Serum specimens for test of HBV-DNA were collected on the same day of liver biopsy and stored at $-70^{\circ} \mathrm{C}$ until use. Serum HBV-DNA was assayed by spot hybridisation techniques using ${ }^{32} \mathrm{P}$ labelled cloned HBV-DNA, as reported previously. ${ }^{21}$

Liver specimens were obtained by percutaneous needle biopsy with a Menghini needle. Fragments of specimens were snap frozen in isopentane cooled with liquid nitrogen and stored at $-70^{\circ} \mathrm{C}$ until use. Samples of the same biopsy specimens were also fixed in $10 \%$ formaldehyde and embedded in paraffin wax for routine histological diagnosis. Cryostat sections $(5 \mu \mathrm{m})$ were dried overnight at room temperature and fixed in carbon tetrachloride at $4^{\circ} \mathrm{C}$ for 10 minutes, followed by an extensive wash with phosphate buffered saline $(\mathrm{pH} 7 \cdot 2)$ before staining. Intrahepatic expression of

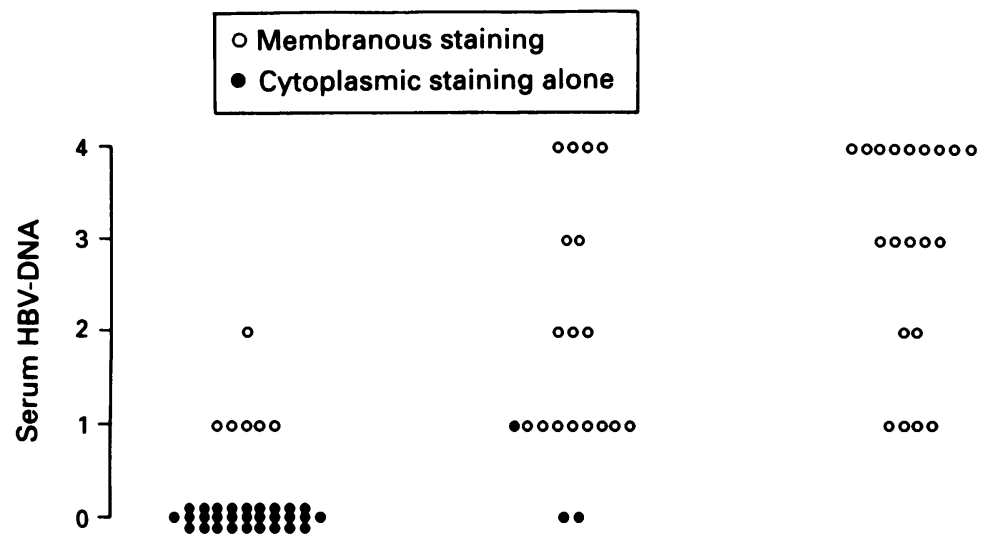

\begin{tabular}{|c|c|c|}
\hline \multirow[t]{2}{*}{ Negative } & $\begin{array}{l}\text { Predominantly } \\
\text { cytoplasmic }\end{array}$ & $\begin{array}{l}\text { Predominantly } \\
\text { nuclear }\end{array}$ \\
\hline & atocyte $\mathrm{HBcAg}$ & \\
\hline
\end{tabular}

Figure 1 Correlation between serum levels of $H B V-D N A$ and hepatocyte staining of $H B c A g$ in 75 patients with chronic hepatitis $B$. Serum levels of $H B V-D N A$ were semiquantitatively scored on a 0 to $4+$ scale, corresponding to undetectable, $\leq 500 \mathrm{pg} / \mathrm{ml}$, $501-1000 \mathrm{pg} / \mathrm{ml}, 1001-2000 \mathrm{pg} / \mathrm{ml}$, and $>2000 \mathrm{pg} / \mathrm{ml}$. The empty circles indicate patients with membranous staining of $\mathrm{HBs} A \mathrm{~g}$ and the filled circles indicate patients with solely cytoplasmic staining of HBsAg. Spearman's rank correlation coefficient $=-0 \cdot 64$, $p<0 \cdot 001$.
$\mathrm{HBcAg}$ was studied by indirect immunofluorescence using rabbit anti-HBc (Dako), followed by fluorescein isothiocyanate (FITC) labelled swine anti-rabbit immunoglobulin $\mathrm{G}$. Intrahepatic expression of $\mathrm{HBsAg}$ was studied by indirect immunofluorescence using murine monoclonal anti-HBs (Chemicon), followed by FITC conjugated rabbit anti-mouse immunoglobulin G (Jackson Immuno Research Laboratories).

Statistical analyses were performed using $\chi^{2}$ test with Yate's correction, Wilcoxon rank sum test, or Spearman's rank correlation where appropriate.

\section{Results}

Hepatocyte staining of $\mathrm{HBcAg}$ was detected in 40 patients, including 20 with predominantly nuclear staining and 20 with predominantly cytoplasmic staining. Serum HBV-DNA was detected in 44 patients, including 20 with levels $>1000 \mathrm{pg} / \mathrm{ml}$ and 24 with levels $\leq 1000 \mathrm{pg} / \mathrm{ml}$. As shown in table 2, the concordance between serum HBV-DNA and hepatocyte staining of HBcAg was $89 \cdot 3 \%(67 / 75)$.

Figure 1 summarises the correlation between serum levels of HBV-DNA and hepatocyte staining of HBcAg. Of the 44 patients positive for serum HBV-DNA, 38 (86.4\%) had $\mathrm{HBcAg}$ detectable in liver. All of the 20 patients with serum levels of HBV-DNA $>1000 \mathrm{pg} / \mathrm{ml}$ had detectable $\mathrm{HBcAg}$ in liver, with $70 \%(14 / 20)$ predominantly in the nucleus and $30 \%(6 / 20)$ predominantly in the cytoplasm, whereas only $75 \%(18 / 24)$ of those with serum levels of HBVDNA $\leq 1000 \mathrm{pg} / \mathrm{ml}$ had detectable $\mathrm{HBcAg}$ in liver $(\mathrm{p}<0.05)$, with $67 \%(12 / 18)$ predominantly in the cytoplasm and $33 \%(6 / 18)$ predominantly in the nucleus $(\mathrm{p}<0.05)$. Serum levels of HBV-DNA were significantly higher in patients with predominantly nuclear staining of $\mathrm{HBcAg}$ than in those with predominantly cytoplasmic staining of $\mathrm{HBcAg}(\mathrm{p}<0.01)$. Five of six patients who had HBV-DNA detectable in serum without hepatocyte staining of $\mathrm{HBcAg}$ had levels of HBV-DNA $\leq 500 \mathrm{pg} / \mathrm{ml}$.

Hepatocyte staining of HBsAg was detected in all of the 75 study patients, including six with purely membranous staining, 32 with purely cytoplasmic staining, and 37 with mixed membranous and cytoplasmic staining. Figure 2 summarises the correlation between serum levels of HBV-DNA and hepatocyte staining of HBsAg. All but one of 44 patients with serum HBV-DNA, including the six patients who had

Table 2 Results of immunostaining of $\mathrm{HBcAg}$ on hepatocyte and serum $H B V-D N A$ in 75 patients with chronic type $B$ hepatitis

\begin{tabular}{lrrll}
\hline & \multicolumn{4}{c}{ Hepatocyte HBcAg/serum $H B V-D N A$} \\
\cline { 2 - 5 } Category & $+1-$ & $-1-$ & $-1+$ & $+1-$ \\
\hline HBeAg positive CPH & 20 & 1 & 1 & 0 \\
HBeAg positive CAH & 15 & 3 & 4 & 0 \\
Anti-HBe positive CAH & 3 & 1 & 1 & 0 \\
Anti-HBe positive MHC & 0 & 24 & 0 & 2 \\
Total & 38 & 29 & 6 & 2 \\
\hline
\end{tabular}

$\mathrm{HBcAg}=$ hepatitis $\mathrm{B}$ core antigen; $\mathrm{HBV}=$ hepatitis $\mathrm{B}$ virus. For other abbreviations see table 1 . 


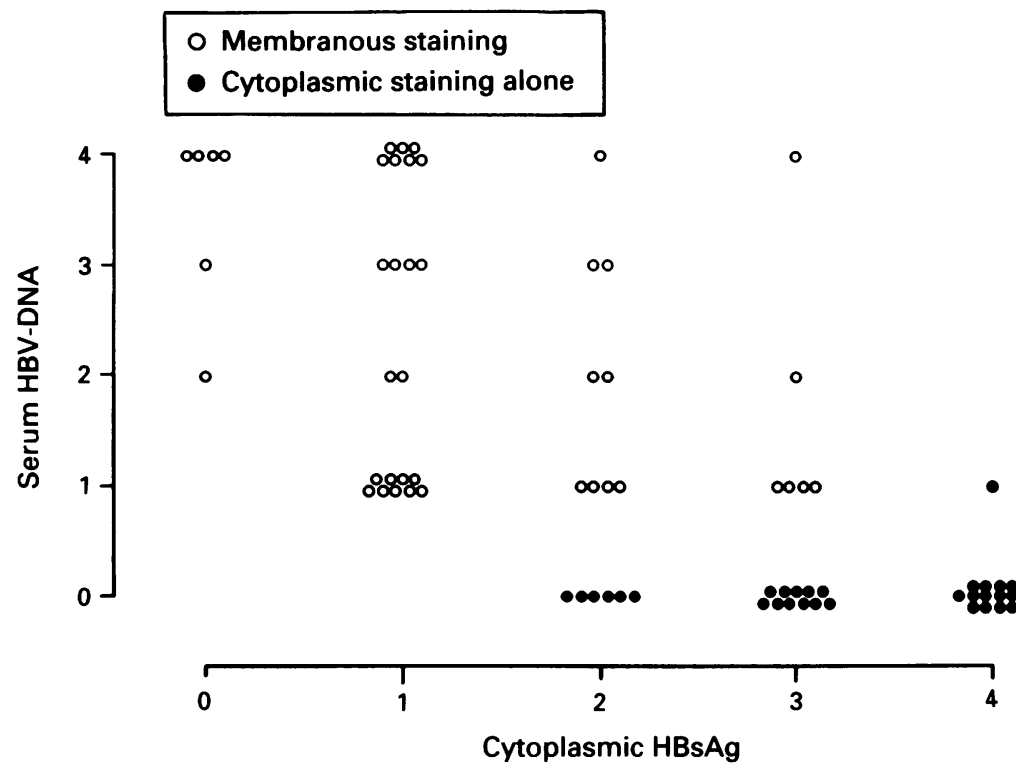

Figure 2 Correlation between serum levels of $H B V-D N A$ and hepatocyte staining of $H B c A g$ in 75 patients with chronic hepatitis $B$. Serum levels of $H B V-D N A$ were semiquantitatively scored on a 0 to $4+$ scale, corresponding to undetectable, $\leq 500 \mathrm{pg} / \mathrm{ml}$, $501-1000 \mathrm{pg} / \mathrm{ml}, 1001-2000 \mathrm{pg} / \mathrm{ml}$, and $>2000 \mathrm{pg} / \mathrm{ml}$. The degree of cytoplasmic staining of $\mathrm{HBs} \mathrm{Ag}$ was semiquantitatively scored on a 0 to $4+$ scale, corresponding to positivity in $0 \%, 1-10 \%, 11-25 \%, 26-50 \%$, and $>50 \%$ of hepatocytes examined. The empty circles indicate patients with membranous staining of $\mathrm{HBs} A \mathrm{~g}$ and the filled circles indicate patients with solely cytoplasmic staining of $H B s A g$. Spearman's rank correlation coefficient $=-0.64, p<0.001$ possible function of the nuclear localisation of HBcAg might be to transport daughter viral genomes from the cytosol to the nucleus and then direct the synthesis of additional viral RNA and eventually increase the number of progeny particles produced by the infected cells.

About $8 \%$ of patients in the present series had HBV-DNA detectable in serum without hepatocyte staining of $\mathrm{HBcAg}$. This figure is relatively lower compared with the $9-23 \%$ reported previously by others. ${ }^{12-15}$ As shown in fig 1 , serum levels of HBV-DNA in these patients were usually relatively low compared with those with detectable hepatocyte $\mathrm{HBcAg}$. The possibility of focal predominantly cytoplasmic staining of $\mathrm{HBcAg}$ cannot be excluded. In addition, the indirect immunofluorescence techniques on frozen sections of liver specimens used in the present study have been shown to have improved sensitivity to detect $\mathrm{HBcAg}$ in the cytoplasm ${ }^{23}$ and thus might have less sampling error compared with other studies. ${ }^{12-15}$ Another 3\% of patients in the present series had $\mathrm{HBcAg}$ staining in the liver without detectable HBV-DNA in serum using spot hybridisation techniques. This figure is similar to the $0-3 \%$ reported previously by others. ${ }^{12-15}$ Although the possibility of false positive immunostaining of $\mathrm{HBcAg}$ cannot be excluded, ${ }^{18}$ the presence of low levels of viral replication in these patients should be further investigated by serum HBVDNA assay using polymerase chain reaction.

In keeping with the previous observations, ${ }^{12519}$ the present data showed that HBsAg was stained diffusely on the hepatocyte membrane, in association with variable degrees of cytoplasmic staining during the phase of active viral replication, while HBsAg was distributed solely in the cytoplasm during the non-replicative phase. Perhaps the more important finding of the present study is that serum levels of HBV-DNA correlated inversely with the degrees of cytoplasmic staining of HBsAg (fig 2). These findings suggested that there is efficient export of intracellular $\mathrm{HBsAg}$ packed with HBV-DNA and nucleocapsid protein as a complete viron during active viral replication, and reduced export of $\mathrm{HBsAg}$ resulting in accumulation of intracellular $\mathrm{HBsAg}$ when viral replication decreases. Another important finding of the present study is that the concordance between membranous staining of $\mathrm{HBsAg}$ on the hepatocyte and serum HBV-DNA was significantly higher than that between hepatocyte expression of $\mathrm{HBcAg}$ and serum HBV-DNA, suggesting that hepatocyte membranous staining of HBsAg is more sensitive and specific than hepatocyte staining of $\mathrm{HBcAg}$ as a marker of active hepatitis $B$ virus replication. The mechanism of membranous staining of $\mathrm{HBsAg}$ during active viral replication is uncertain. Of note is that the distribution of membranous staining of $\mathrm{HBsAg}$ is usually very diffuse. The population of cells with membranous staining of $\mathrm{HBsAg}$ should thus be larger than the population of cells in which the virus replicates. It seems less likely that membranous staining of HBsAg indicates expression of viral antigen on the cell membrane of infected hepatocytes. predominantly nuclear staining of $\mathrm{HBcAg}$ than in those with predominantly cytoplasmic staining of $\mathrm{HBcAg}$. These findings are in keeping with the suggestion by $\mathrm{Ou}$ et $a l^{22}$ that one 
Instead it is suggested that the diffuse membranous staining of $\mathrm{HBsAg}$ during active $\mathrm{HBV}$ replication indicates absorption of circulating hepatitis $B$ virus virons on the liver cell surface; the virons are surrounded by HBsAg which contains polymerised human albumin receptor and could thus be absorbed on the liver cell surface. ${ }^{2425}$

In conclusion, membranous staining of HBsAg on the hepatocyte correlated excellently with serum HBV-DNA and could be recognised as a marker of active hepatitis $B$ virus replication. It was suggested that membranous staining of $\mathrm{HBsAg}$ possibly indicates absorption of circulating hepatitis $B$ virus virons on the cell surface rather than expression of viral proteins on the cell membrane of infected cells.

The authors thank Ms Tsai MH and Leu HL for preparation of this manuscript.

1 Gudat F, Bianchi L, Sonnabend W, Thiel G, Aenishaenslin W, Stalder GA. Pattern of core and surface expression in liver tissue reflects state of specific immune response in hepatitis B. Lab Invest 1975;32:1-9.

2 Ray MB, Desmet VJ, Bradburne AF, Desmyter J, Fevery J, DeGroote J. Differential distribution of hepatitis B surface antigen and hepatitis B core antigen in liver of hepatitis antigen and hepatitis B core antigen in liver

3 Yamada G, Nakane PK. Hepatitis B core and surface antigens in liver tissue. Light and electron microscopic localisation by the peroxidase-labeled antibody method. $L a b$ Invest 1977;36:649-59.

4 Huang SN, Neurath AR. Immunohistologic demonstration of hepatitis B viral antigens in liver with reference to its significance in liver injury. Lab Invest 1979;40:1-17.

5 Chu CM, Liaw YF. Intrahepatic distribution of hepatitis B surface and core antigens in chronic hepatitis B virus infection: hepatocyte with cytoplasmic/membranous hepatitis B core antigen as a possible target for immune hepatocytolysis. Gastroenterology 1987;92:220-5.

6 Hsu HC, Su IJ, Lai MY, Chen DS, Chang MH, Chuang $\mathrm{SM}$, et al. Biologic and prognostic significance of hepatitis $\mathrm{B}$ core antigen expression in the natural course of chronic B core antigen expression in the natural course of chron

7 Yoo JY, Howard R, Waggoner JG, Hoofnagle JH. Peroxidase-anti-peroxidase detection of hepatitis $\mathrm{B}$ surface and core antigen in liver biopsy specimens from patients with chronic type B hepatitis. F Med Virol 1987;23:273-81.

8 Kakumu S, Arao M, Yoshioka K, Tsutsumi Y, Inoue $M$ Distribution of $\mathrm{HBcAg}$ in hepatitis B detected by immunoperoxidase staining with three different preparation of anti-HBc antibodies. F Clin Pathol 1989;42:284-8.
9 Weller IVD, Fowler MJF, Monjardino J, Thomas HC. The detection of HBV-DNA in serum by molecular hybridization. $\mathcal{F}$ Med Virol 1982;9:273-80.

10 Karayiannis P, Fowler MJF, Lok ASF, Greenficed G, Monjardino J, Thomas HC. Detection of serum HBV-DNA by molecular hybridisation: correlation with $\mathrm{HBeAg} /$ anti$\mathrm{HBe}$ status, racial origin and liver histology. $f$ Hepatol 1985;1:99-106.

11 Berninger M, Hammer M, Hoyer B, Gerin JL. An assay for the detection of the DNA genome of hepatitis B virus in the detection of the DNA genom
serum. $\mathcal{7}$ Med Virol 1982;9:57-68.

12 Bonino F, Hoyer B, Nelson J, Engle R, Verme G, Gerin JL. Hepatitis B virus DNA in the sera of $\mathrm{HBsAg}$ carriers: a marker of active hepatitis $B$ virus replication in the liver. Hepatology 1981;1:386-91.

13 Hadziyannis SJ, Leiberman HM, Karvountzis GB, Shafritz $\mathrm{DA}$. Analysis of liver disease, nuclear $\mathrm{HBcAg}$, viral replication, and hepatitis B virus DNA in liver and serum of $\mathrm{HBeAg}$ vs anti-HBe positive carriers of hepatitis B virus. Hepatology 1983;3:656-62.

14 Freiman J, Eckstein R, McCaughan G, Parsons C, Davies JS, Diegutis P, et al. Significance of serum and hepatic markers of hepatitis B viral infection in HBsAg-positive and HBsAg-negative chronic active hepatitis. Hepatology and HBsAg-neg

15 Wu JC, Lee SD, Wang HY, Ting LP, Tsai YT, Tsay SH, et al. Correlation between hepatic hepatitis $\mathrm{B}$ core antigen and serum hepatitis B virus-DNA levels in patients with chronic hepatitis B virus infection in Taiwan. Arch Pathol Lab Med 1987;111:181-4.

16 Chu CM, Liaw YF. Hepatocyte expression of $\mathrm{HBcAg}$ and serum HBeAg in hepatitis B. Comparison of polycional and monoclonal antibodies during a trial of interferon. $f$ Clin Pathol 1991;44:21-4.

$17 \mathrm{Chu}$ CM, Liaw YF. Immunohistological study of intrahepatic expression of hepatitis B core and e antigen in chronic type B hepatitis. $\mathcal{F}$ Clin Pathol 1992;45:791-5.

18 Goodman ZO, Langloss JM, Bratthauer GL, Ishak KG Immunohistochemical localization of hepatitis B surface Immunohistochemical localization of hepatitis B surface source of false positive staining. Am f Clin Pathol 1988; source of

19 Montano L, Miescher GC, Goodall AH, Wiedmann KH, Janossy G, Thomas HC. Hepatitis B virus and HLA antigen display in the liver during chronic hepatitis $\mathrm{B}$ virus infection. Hepatology 1982;2:557-61.

20 International Group. Acute and chronic hepatitis revisited. Lancet 1977;ii:914-9.

21 Chu CM, Karayiannis P, Fowler MJF, Monjardino J, Liaw YF, Thomas HC. Natural history of chronic hepatitis B virus infection in Taiwan: studies of hepatitis B virus DNA in serum. Hepatology 1985;5:431-4.

$22 \mathrm{Ou} \mathrm{JH}$, Yeh CT, Yen TSB. Transport of hepatitis B virus precore protein into the nucleus after cleavage of its signal precore protein into the nucleus after
peptide. F Virol 1989;63:5238-43.

23 Gowans EJ, Burrell CJ. Widespread presence of cytoplasmic $\mathrm{HBcAg}$ in hepatitis B infected liver detected by improved HBcAg in hepatitis B infected liver detected by improved

24 Imai M, Yanase Y, Mojri T. A receptor for polymerized human and chimpanzee albumins on hepatitis B virus particles co-occurring with $\mathrm{HBeAg}$. Gastroenterology 1979 76:241-7.

25 Thung SN, Gerber MA. Hepatitis B virus and polyalbumin binding sites. Gastmenterology 1983;83:466-8. 